Karen A. Brown MD FRCPC, Bruno Bissonnette MD FRCPC, Brian McIntyre MD FRCPC

\section{Hyperkalaemia during rapid blood transfusion and hypovolaemic cardiac arrest in children}

l'aide de TSR. Nous en avons conclu que si la $\left[\mathrm{K}^{+}\right]_{\text {plasma }} d u$ sang transfusé était $\geq 10 \mathrm{mmol} \cdot L^{-1}$, l'utilisation de TSR combinée à un faible débit cardiaque pouvait entraîner de l'hyperkaliémie. Nous avons alors colligé rétrospectivement la kaliémie mesurée lors de 138 càs d'arrêt cardiaque chez des enfants, pour s'apercevoir quelle s'élevait à $8,23 \pm 1,99 \mathrm{mmol} \cdot I^{-1}$ chez ceux qui avaient reçu des TSR durant la réanimation alors qu'elle $n$ 'était que de 5,63 $\pm 2,39$ chez les autres $(P<0,05)$. Les TSR employées chez ces enfants hypovolémiques au faible débit cardiaque ont pu contribuer à l' hyperkaliémie observée lors de l'arrêt cardiaque.

A morbidity and mortality review of cardiac arrests at our institution showed that a number of intraoperative cardiac arrests was associated with hyperkalaemia. Cardiac arrest was defined as severe hypotension which required the institution of CPR. This was unexpected because hyperkalaemia during cardiac arrest is unusual. The common denominator, in the cardiac arrests associated with hyperkalaemia, seemed to be the rapid administration of blood to correct hypovolaemia. Samples drawn during the cardiac arrests had been aspirated from indwelling radial arterial lines. Therefore, the potassium concentrations

$\begin{array}{ll}\text { Abbreviations } \\ \mathrm{CO} & \text { - cardiac output } \\ \mathrm{Hct}_{\mathrm{Pt}} & \text { - haematocrit of patient } \\ \mathrm{Hct}_{\mathrm{Tr}} & \text { - haematocrit of transfusion } \\ \mathrm{K} & \text { - rate constant }=\dot{\mathrm{Q}}_{\mathrm{Tot}} / \mathrm{V}_{1} \\ {[\mathrm{~K}]} & \text { - plasma potassium concentration } \\ \mathrm{K}_{\mathrm{Pt}} & \text { - plasma [K] of patient } \\ \mathrm{K}_{\mathrm{Tr}} & \text { - plasma [K] of transfusion } \\ \mathrm{K}_{\mathrm{Tot}} & \text { - plasma [K] of inflow } \\ \mathrm{RBCconc} & \text { - red blood cell concentrate } \\ \mathrm{RBT}_{\mathrm{T}} & \text { - rapid blood transfusion } \\ \mathrm{rWB} & \text { - reconstituted whole blood } \\ \dot{\mathrm{Q}}_{\mathrm{Pt}} & \text { - rate of plasma flow of patient } \\ \dot{\mathrm{Q}}_{\mathrm{Tr}} & \text { - rate of plasma flow of transfusion } \\ \dot{\mathrm{Q}}_{\mathrm{Tot}} & \text { - rate of plasma flow of inflow } \\ \mathrm{V}_{\mathrm{I}} & \text { - volume of central compartment } \\ \mathrm{VR} & \text { - venous return }\end{array}$


closely approximated the concentrations in the central and, in particular, the coronary circulation. To simulate events during RBT and hypovolaemic cardiac arrest, which might lead to hyperkalaemia, we developed a one compartment model of the central circulation and used it to simulate hypovolaemic cardiac arrest in a child.

In a parallel retrospective review, we hypothesized that cardiac arrests in which rapid blood transfusion was utilized would demonstrate an elevated plasma potassium concentration (plasma $[\mathrm{K}]$ ), defined as $>6 \mathrm{mmol} \cdot \mathrm{L}^{-1}$, and that cardiac arrests in which rapid blood transfusion was not utilized, would not be associated with hyperkalaemia. It was recognized that such a review would have limitations. Although cardiac arrest would be common to all patients, the patient population would not be homogeneous. Variables, which are known to influence the plasma [K] such as acid base status, the degree of cellular insult, the administration of resuscitation drugs and the site of blood sampling, would be uncontrolled. These reservations notwithstanding, the retrospective review was undertaken.

This paper reports both the model simulation and the results of the retrospective review.

\section{Methods}

\section{Model simulation}

A one compartment model was developed with the following characteristics. The central circulation was considered as a single homogeneous compartment of volume $V_{1}$ receiving two sources of flow, the patient's cardiac output and the blood transfusion which combined to give the total venous return, $\dot{Q}_{\text {Tot }}$. Both sources contained potassium at concentrations, $\mathrm{K}_{\mathrm{P}}$ and $\mathrm{K}_{\mathrm{Tr}}$ respectively, which combined to give a uniform inflow potassium concentration $\mathrm{K}_{\text {Tot }}$ (Figure 1), where the subscripts $\mathrm{Pt}, \mathrm{Tr}$ and Tot refer to the patient, the transfusion and the inflow respectively; $\dot{Q}$ refers to the rate of plasma flow and $K$, to the plasma [K].

The amount of potassium in the plasma fraction of the inflow (FreeK $\mathrm{K}_{\mathrm{To}}$ ) was equal to the amount of free potassium contained in the venous return from the patient $\left(\right.$ FreeK $\left._{\mathrm{Pr}}\right)$ and the transfusion $\left(\right.$ FreeK $_{\mathrm{Tr}}$ ) such that:

$$
\begin{aligned}
\text { FreeK }_{\text {Tot }} & =\text { FreeK }_{\mathrm{Pt}_{t}}+\text { FreeK }_{\mathrm{Tr}} \\
& =\mathrm{K}_{\mathrm{Tot}} \times \dot{\mathrm{Q}}_{\mathrm{Tot}}
\end{aligned}
$$

And

$\mathrm{K}_{\mathrm{Tot}}=\left(\mathrm{K}_{\mathrm{Pt}} \times \frac{\dot{\mathrm{Q}}_{\mathrm{Pt}}}{\dot{\mathrm{Q}}_{\mathrm{Tot}}}\right)+\left(\mathrm{K}_{\mathrm{Tr}} \times \frac{\dot{\mathrm{Q}}_{\mathrm{Tr}}}{\dot{\mathrm{Q}}_{\mathrm{Tol}}}\right)$

(See Appendix for the derivation of Equation 2.)

The rate of rise of $K(t)$, in the central circulation, was

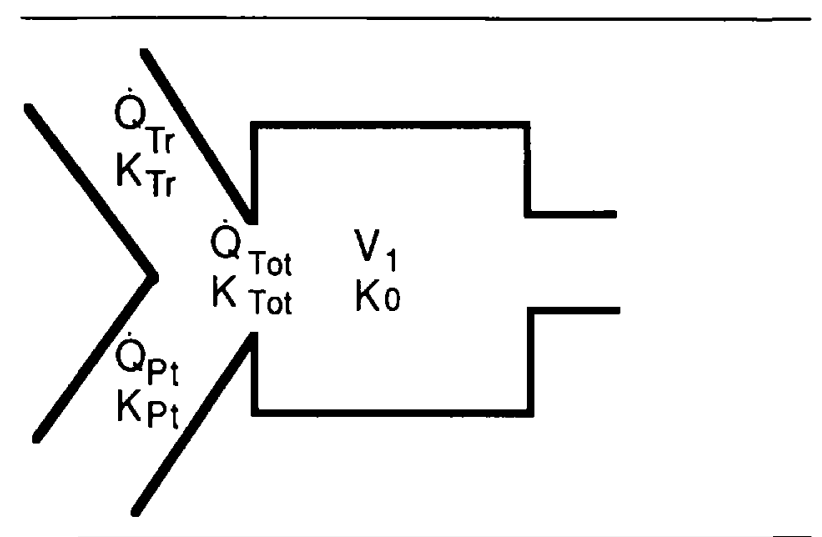

FIGURE 1 One compartment model of the central circulation, where $\mathrm{V}_{1}$ is the volume of the central circulation; $\dot{\mathrm{Q}}_{\mathrm{Ta}}, \dot{\mathrm{Q}}_{\mathrm{Tr}}$ and $\dot{\mathrm{Q}}_{\mathrm{P}}$ are the plasma flow of the inflow, transfusion (TR) and venous return (VR) respectively; $K_{T o t}, K_{T r}$ and $K_{P_{t}}$ are the plasma [K] of the inflow, transfusion, and patient. $K_{0}$, the initial plasma $[K]$ of the central compartment, was assumed to be $4 \mathrm{mmol} \cdot \mathrm{L}^{-1}$.

described by the following exponential equation ${ }^{1}$ :

$$
K(t)=K_{\text {Tot }}\left(1-\mathrm{e}^{-k(t)}\right)+\left(K_{0} e^{-k(t)}\right)
$$

where $\mathrm{k}$, the rate constant was equal to $\dot{\mathrm{Q}}_{\mathrm{Tot}} / \mathrm{V}_{1}$ and the initial potassium concentration, $K_{\mathrm{o}}$, was assumed to equal to $4 \mathrm{mmol} \cdot \mathrm{L}^{-1}$.

The model was used to simulate an anaesthetized, hypovolaemic hypotensive child $(10-15 \mathrm{~kg})$, with a cardiac output of $50 \mathrm{ml} \cdot \mathrm{min}^{-1}$ and who was transfused rapidly at a rate of $100-200 \mathrm{ml} \cdot \mathrm{min}^{-1}$. A patient haematocrit $\left(\mathrm{Hct}_{\mathrm{Pt}}\right)$ of $\mathbf{0 . 3}$ and a transfusion haematocrit $\left(\mathrm{Hct}_{\mathrm{Tr}}\right)$ of 0.5 were assumed so that: $\dot{\mathrm{Q}}_{\mathrm{Pt}}=35 \mathrm{ml} \cdot \mathrm{kg}^{-1}$. $\min ^{-1}, \mathrm{Q}_{\mathrm{Tr}}=5-10 \mathrm{ml} \cdot \mathrm{kg}^{-1} \cdot \mathrm{min}^{-1}$ (See Appendix). Therefore the ratio $\dot{\mathrm{Q}}_{\mathrm{Tr}} / \dot{\mathrm{Q}}_{\mathrm{Tot}}=0.14-0.22$. The rate constant, $\mathrm{k}$, was 4.8-5.4 min $^{-1}$ (See Discussion). A K $\mathrm{Tr}_{\mathrm{Tr}}$ of $20-30 \mathrm{mmol} \cdot \mathrm{L}^{-1}$ was assumed and from Equation 2 , $\mathrm{K}_{\text {Tot }}$ ranged from $6.3-9.8 \mathrm{mmol} \cdot \mathrm{L}^{-1}$.

\section{Patient review}

With Institutional Approval, patients who had suffered cardiac arrest were identified from two sources: (1) the 1988 computer records of the Quality Assurance Review Committee and (2) the morbidity and mortality records of the Department of Anaesthesia. The intraoperative arrest records for 1985 to 1988 were reviewed. Cardiac arrests occurring in the neonatal ICU or during procedures requiring cardiopulmonary bypass were excluded.

Inclusion criteria were: (1) a cardiac arrest requiring CPR and (2) a plasma potassium concentration from blood drawn with chest compressions in progress. The $\mathrm{pH}, \mathrm{PCO}_{2}, \mathrm{PO}_{2}$ and the ionized [Ca] at the time of the arrest and the control plasma [K] were also recorded. In addition the amount and the age of the blood transfused and resuscitation drugs administered were noted. Patients 
TABLE I Plasma [K], acid basc, and demographic data in the non-transfused group.

\begin{tabular}{|c|c|c|c|c|c|c|}
\hline \multirow[b]{2}{*}{ Patient } & \multirow[b]{2}{*}{$\begin{array}{l}\text { Age } \\
(y r)\end{array}$} & \multirow[b]{2}{*}{ Diagnosis } & \multicolumn{2}{|l|}{ Control } & \multicolumn{2}{|c|}{ Arrest } \\
\hline & & & $\begin{array}{l}(K) \\
\left(m m o l \cdot L^{-1}\right)\end{array}$ & $\begin{array}{l}{[K]} \\
\left(\mathrm{mmol} \cdot \mathrm{L}^{-1}\right)\end{array}$ & $p H$ & $\begin{array}{l}\mathrm{PO}_{2} \\
(\mathrm{mmH} \mathrm{g})\end{array}$ \\
\hline 1 & 16.0 & Trauma & 4.5 & 4.8 & 7.12 & 25.0 \\
\hline 2 & 2.5 & Cardiac & 4.4 & 5.4 & 6.99 & 11.0 \\
\hline $3^{*}$ & 0.8 & Neurologic & 3.2 & 6.3 & 7.23 & 120.0 \\
\hline $4^{*}$ & 16.0 & Trauma & 5.2 & 5.2 & 7.77 & 513.0 \\
\hline $5^{*}$ & 9 & Cardiac & 2.5 & 12.8 & 7.42 & 285.0 \\
\hline 6 & 1.5 & Cardiac & NA & 4.8 & 6.83 & 29.0 \\
\hline 7 & 5.0 & Near-drowning & 3.9 & 4.5 & 7.36 & 68.0 \\
\hline 8 & 1.5 & Cardiac & 4.3 & 4.9 & 7.5 & 91.0 \\
\hline 9 & Term & Diaphragmatic hernia & 3.8 & 2.5 & 7.0 & 54.0 \\
\hline 10 & 1.5 & Trauma & 3.9 & 2.5 & NA & NA \\
\hline 11 & 11.0 & Cardiac & 4.6 & 3.1 & 7.3 & 64.0 \\
\hline 12 & 9.0 & Neurologic & 3.4 & 4.8 & 7.4 & NA \\
\hline \multirow[t]{2}{*}{13} & Term & Diaphragmatic hernia & 3.5 & 5.9 & NA & NA \\
\hline & & & 8.1 & 7.8 & NA & NA \\
\hline 14 & $2 \mathrm{wk}$ & Cardiac & 3.9 & 3.9 & 7.3 & 68.0 \\
\hline 15 & 10.0 & Cardiac & 5.4 & 7.4 & NA & NA \\
\hline 16 & 0.8 & Renal failure & 6.3 & 8.6 & 7.26 & 18.0 \\
\hline 17 & 1.0 & Sepsis & 5.1 & 5.1 & NA & NA \\
\hline 18 & 0.5 & Renal failure & 6.5 & 6.7 & NA & NA \\
\hline Mean & & & 4.58 & 5.63 & 7.27 & \\
\hline $\pm S D$ & & & 1.36 & 2.39 & 0.25 & \\
\hline
\end{tabular}

*Intraoperative cardiac arrests.

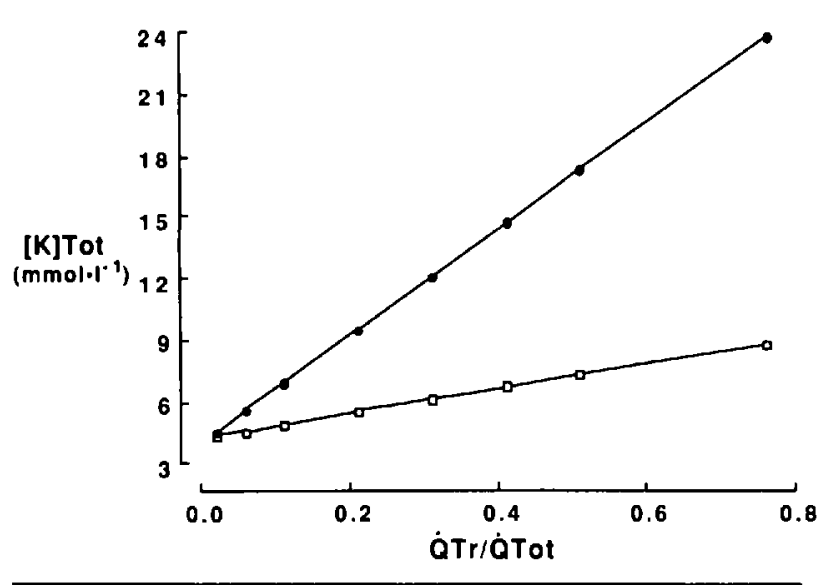

FIGURE 2 The effect of the ratio $\dot{\mathrm{Q}}_{\mathrm{Tr}} / \dot{\mathrm{Q}}_{\mathrm{Tot}}$, on $\mathrm{K}_{\mathrm{Tot}}$ for values of $\mathrm{K}_{\mathrm{Tr}}$ ranging from $10 \mathrm{mmol} \cdot \mathrm{L}^{-1}(\square \ldots \square)$ to $30 \mathrm{mmol} \cdot \mathrm{L}^{-1}(-\ldots)$. (A $\mathrm{K}_{\mathrm{Pr}}$ of $4.0 \mathrm{mmol} \cdot \mathrm{L}^{-1}$ was assumed.) As long as the ratio, $\dot{\mathrm{Q}}_{\mathrm{Tr}} / \dot{\mathrm{Q}}_{\mathrm{Tot}}$, remained less than $0.1, \mathrm{~K}_{\text {Tol }}$ was less than $6 \mathrm{mmol} \cdot \mathrm{L}^{-1}$ regardless of the value of $\mathrm{K}_{\mathrm{Tr}}$. Transfused blood containing a potassium poor plasma fraction $\left(K_{T r}=10 \mathrm{mmol} \cdot \mathrm{L}^{-1}\right)$ rcsulted in a $\mathrm{K}_{\mathrm{Tot}}>8 \mathrm{mmol} \cdot \mathrm{L}^{-1}$ when the ratio $\dot{\mathrm{Q}}_{\mathrm{Tr}} / \dot{\mathrm{Q}}_{\mathrm{Tot}}$ was $>0.7$. In contrast, transfused blood whose plasma fraction was rich in frec potassium $\left(\mathrm{K}_{\mathrm{Tr}}>20 \mathrm{mmol} \cdot \mathrm{L}^{-1}\right)$ resulted in a $\mathrm{K}_{\mathrm{TOl}}>8 \mathrm{mmol} \cdot \mathrm{L}^{-1}$ when the ratio $\dot{\mathrm{Q}}_{\mathrm{Tr}} / \dot{\mathrm{Q}}_{\mathrm{Tor}}$ was $<0.3$.

were divided into two groups, a non-RBT group who were not being transfused and a RBT group for whom resuscitation included a rapid blood transfusion.
Intra-group differences between the control and the arrest plasma [K] were assessed with a paired t test. Intergroup differences between the two groups were assessed with an unpaired $t$ test. $^{2}$ A $\boldsymbol{P}$-value of 0.05 was accepted for statistical significance.

\section{Results}

\section{Model simulation}

$A K_{\mathrm{Pt}}$ of $4.0 \mathrm{mmol} \cdot \mathrm{L}^{-1}$ was assumed. Figure 2 illustrates the effect of the ratio $\dot{\mathrm{Q}}_{\mathrm{Tr}} / \dot{\mathrm{Q}}_{\mathrm{Tot}}$, on $\mathrm{K}_{\mathrm{Tot}}$ for values of $\mathrm{K}_{\mathrm{Tr}}$ ranging from 10 to $30 \mathrm{mmol} \cdot \mathrm{L}^{-1}$. As long as the ratio, $\dot{\mathrm{Q}}_{\mathrm{Tr}} / \dot{\mathrm{Q}}_{\mathrm{Tot}}$, remained less than 0.1 , the $\mathrm{K}_{\mathrm{Tot}}$ was less than $6 \mathrm{mmol} \cdot \mathrm{L}^{-1}$ regardless of the value of $\mathrm{K}_{\mathrm{Tr}}$. Transfusion blood containing a potassium poor plasma fraction $\left(\mathrm{K}_{\mathrm{rr}}=\right.$ $10 \mathrm{mmol} \cdot \mathrm{L}^{-1}$ ) resulted in a $\mathrm{K}_{\text {Tot }}>8 \mathrm{mmol} \cdot \mathrm{L}^{-1}$ when the ratio $\dot{\mathrm{Q}}_{\mathrm{Tr}} / \dot{\mathrm{Q}}_{\mathrm{Tot}}$ was $>0.7$. In contrast, transfusion with blood whose plasma fraction was rich in free potassium $\left(\mathrm{K}_{\mathrm{Tr}}>20 \mathrm{mmol} \cdot \mathrm{L}^{-1}\right)$ resulted in a $\mathrm{K}_{\mathrm{Tot}}$ in excess of $8 \mathrm{mmol} \cdot \mathrm{L}^{-1}$ when the ratio $\dot{\mathrm{Q}}_{\mathrm{Tr}} / \dot{\mathrm{Q}}_{\mathrm{Tot}}$ was still less than 0.3 .

The rate of rise of the plasma $[K](K(t))$, during $R B T$ at a rate of $5-10 \mathrm{ml} \cdot \mathrm{kg}^{-1} \cdot \mathrm{min}^{-1}$ during hypovolaemic cardiac arrest, is shown in Figure 3. Most of the increase in $K(t)$ occurred within the first 20 seconds.

\section{Patient review}

Twenty-five of the 138 charts which were reviewed met 


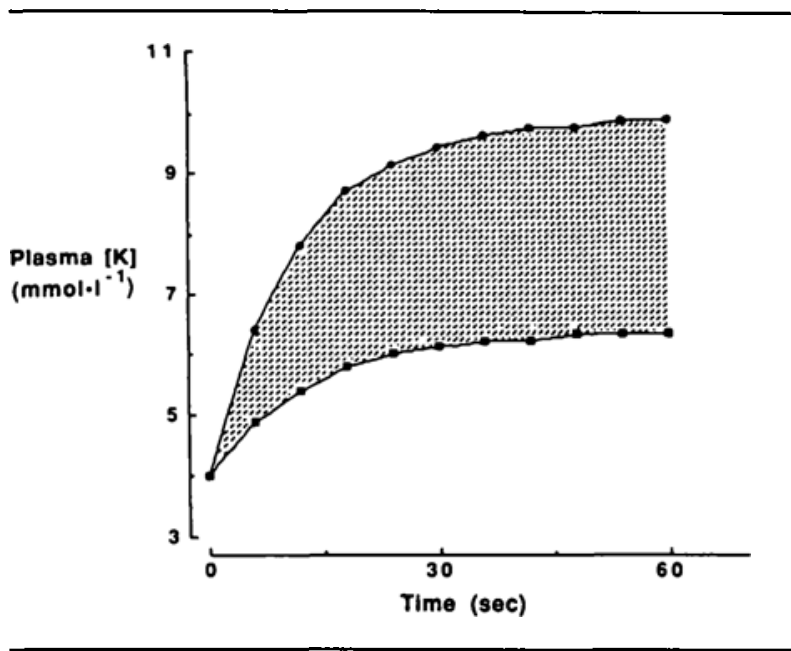

FIGURE 3 Model simulation involving a RBT during severe hypovolaemic hypotension in a child. Values for $\mathrm{K}(\mathrm{t})$, shown in the hatched area, represent conditions which range from (1) a of $\mathrm{K}_{\mathrm{Tr}}=$ $20 \mathrm{mmol} \cdot \mathrm{L}^{-1}$ and $\dot{Q}_{\mathrm{Tr}}=5 \mathrm{ml} \cdot \mathrm{kg} \cdot \mathrm{min}^{-1}$ to (2) a $\mathrm{K}_{\mathrm{Tr}}=30 \mathrm{mmol}$ $\mathrm{L}^{-1}$ and $\dot{\mathrm{Q}}_{\mathrm{Tr}}=10 \mathrm{ml} \cdot \mathrm{kg} \cdot \mathrm{min}^{-1}$. Most of the increase in plasma $[\mathrm{K}]$ occurred within $20 \mathrm{sec}$.

the inclusion criteria. The timing of the blood sample during cardiac arrest varied with the circumstances of the individual arrests but in all cases the plasma $[\mathrm{K}]$ reported was the first plasma $[\mathrm{K}]$ available with $\mathrm{CPR}$ in progress. The time at which the control plasma $[\mathrm{K}]$ was drawn also varied with the clinical situation. In the non-RBT group it was drawn on the day of the arrest, and in the RBT group it was drawn within the hour preceding the cardiac arrest as part of the routine hourly blood work.

In the non-RBT group (Table I), three arrests (patients $\# 3,4,5$ ) occurred intraoperatively. The remainder occurred on the ward or in the ICU. The plasma [K] during cardiac arrest in the non-RBT group ranged from $2.5-12.8 \mathrm{mmol}$. $\mathrm{L}^{-1}$. In this non-RBT group, there were five values of plasma [K] during cardiac arrest in excess of $6.0 \mathrm{mmol}$ $\mathrm{L}^{-1}$. In three of these $(\# 13,16,18)$ the control plasma [K] was $>6.0 \mathrm{mmol} \cdot \mathrm{L}^{-1}$ due to acute renal failure. Patient \#15 was in profound cardiogenic shock for the hour preceding the arrest. Patient \#5, with an arrest plasma $[\mathrm{K}]$ of $12.8 \mathrm{mmol} \cdot \mathrm{L}^{-1}$ had received an inadvertent, uncontrolled infusion of $\mathrm{KCl}$ and was excluded from statistical analysis. The mean control plasma $[\mathrm{K}]$ for the non-RBT group was $5.63 \pm 2.39 \mathrm{mmol} \cdot \mathrm{L}^{-1}$, which was not statistically different from its control value of $4.58 \pm$ $1.36 \mathrm{mmol} \cdot \mathrm{L}^{-1}$.

In the RBT group, all cardiac arrests occurred intraoperatively, during acute haemorrhage and RBT (Table II). All were ASA physical status I patients, and none had been premedicated. All patients had a control plasma $[\mathrm{K}]<5.0 \mathrm{mmol} \cdot \mathrm{L}^{-1}$. In the RBT group, the plasma [K] during cardiac arrest ranged from $6.4-12.3 \mathrm{mmol} \cdot \mathrm{L}^{-1}$ $\left(8.35 \pm 1.90 \mathrm{mmol} \cdot \mathrm{L}^{-1}\right)$ and was statistically higher than the control value of $4.59 \pm 1.01 \mathrm{mmol} \cdot \mathrm{L}^{-1},(P<0.01)$. Three patients in the RBT group (\#1, \#3 and \#4) received epinephrine during resuscitation. The mean control plasma $[\mathrm{K}]$ was not statistically different between the non-RBT and RBT groups. Differences between the arrest plasma $[\mathrm{K}]$ in the non-RBT and RBT groups were statistically significant $(P<0.05)$.

The $\mathrm{pH}$ during cardiac arrest in the RBT group ranged from 7.08 to 7.97 which compared with $\mathrm{pH}$ values ranging from 6.83 to 7.42 in the non-RBT group. Differences in $\mathrm{pH}$ were not tested for statistical significance. The plasma bicarbonate levels given in Table II ranged from 12 to $67 \mathrm{mmol} \cdot \mathrm{L}^{-1}$. Only patient $\# 1$ in Table Il received bicarbonate during resuscitation. The ionized calcium $\left(\left[\mathrm{Ca}^{++}\right]\right)$concentration during cardiac arrest was only available in the RBT-group. It ranged from 0.2 to $1.7 \mathrm{mmol} \cdot \mathrm{L}^{-1}$. Intravenous calcium was being administered during the rapid blood transfusion and resus-

TABLE II Plasma [K], acid-base, and demographic data in the RBT group

\begin{tabular}{|c|c|c|c|c|c|c|c|c|c|}
\hline \multirow[b]{2}{*}{ Patient } & \multirow[b]{2}{*}{$\begin{array}{l}\text { Age } \\
(y r)\end{array}$} & \multirow[b]{2}{*}{$\begin{array}{l}\text { Weight } \\
(\mathrm{kg})\end{array}$} & \multicolumn{2}{|l|}{ Control } & \multicolumn{4}{|c|}{ Arrest } & \multirow[b]{2}{*}{$\begin{array}{l}\text { Age of } \\
\text { blood }\end{array}$} \\
\hline & & & $\begin{array}{l}\left(K^{+}\right) \\
\left(\mathrm{mmol} \cdot \mathrm{L}^{-1}\right)\end{array}$ & $\begin{array}{l}\left(K^{+}\right) \\
\left(\mathrm{mmol} \cdot \mathrm{L}^{-1}\right)\end{array}$ & $p H$ & $\begin{array}{l}\mathrm{PO}_{2} \\
(\mathrm{mmHg})\end{array}$ & $\begin{array}{l}\left(\mathrm{Ca}^{++}\right) \\
\left(\mathrm{mmol} \cdot \mathrm{L}^{-1}\right)\end{array}$ & $\begin{array}{l}{\left[\mathrm{HCO}_{3}^{-}\right]} \\
\left(\mathrm{mmol} \cdot \mathrm{L}^{-1}\right)\end{array}$ & \\
\hline $1^{*}$ & 0.5 & 7.0 & 4.2 & 9.6 & 7.97 & 457 & 1.7 & 67 & $13 \mathrm{~d}$ \\
\hline 2 & 1.5 & 7.0 & 5.0 & 7.3 & 7.30 & NA & 0.8 & NA & $13 \mathrm{~d}$ \\
\hline 3* & I & 8.0 & 3.1 & 7.5 & 7.27 & $59 \mathrm{I}$ & 0.7 & 24 & $13 \mathrm{~d}$ \\
\hline $4^{*}$ & 2 & 11.0 & 4.3 & 12.3 & 7.20 & 439 & 0.8 & 12 & $21 \mathrm{~d}$ \\
\hline \multirow[t]{2}{*}{5} & 2 & 12.0 & 5.0 & 9.0 & 7.36 & 38 & 1.0 & 32 & $>17 d$ \\
\hline & & & 3.6 & 6.4 & 7.35 & 135 & 0.4 & 26 & $>14 d$ \\
\hline 6 & 17 & 33.0 & 5.3 & 7.3 & 7.20 & 371 & 0.2 & 19 & $>18 d$ \\
\hline 7 & 13 & 70.0 & 3.4 & 6.4 & 7.08 & 90 & 0.8 & 20 & $7 \mathrm{~d}$ \\
\hline Mean & & & 4.59 & 8.23 & 7.34 & & & & \\
\hline $\pm S D$ & & & 1.07 & 1.99 & 0.27 & & & & \\
\hline
\end{tabular}

*Ventricular arrythmia. 
citation. The arterial $\mathrm{PO}_{2}$ ranged from 38 to $591 \mathrm{mmHg}$ in the RBT group and from 11 to $513 \mathrm{mmHg}$ in the non-RBT group. Differences in oxygenation during cardiac arrest were not submitted to statistical analysis.

It was not possible to determine the absolute rate of blood transfusion during the period of cardiac arrest from the chart review. However, it was evident that units of rWB were administered quickly. Patients 1 through 6 were transfused with units of reconstituted whole blood (rWB) made by suspending a unit of Red Blood Cell concentrate (RBCconc) in a unit of plasma. The age of the RBCconc being transfused was $\geq 13$ days. Patient \#7 received units of $R B C$ conc which were $\leq 7$ days old. For this patient the units of RBCconc were diluted in $250 \mathrm{ml}$ of normal saline. Three patients had an arrhythmia: \#1 and \#3 had ventricular fibrillation and \#4 had asystole.

No patient in the RBT-group required specific pharmacological treatment for hyperkalaemia observed during cardiac arrest. The elevated plasma $[\mathrm{K}]$ during cardiac arrest was followed serially in the RBT group. In all cases it was $\leq 5.5 \mathrm{mmol} \cdot \mathrm{L}^{-1}$ within one hour of the cardiac arrest. Serial measurements were not consistently recorded in the cardiac arrests in the non-RBT group.

\section{Discussion}

The plasma potassium concentrations during cardiac arrest was higher than the control levels in both groups, although only in the non-RBT group was the difference statistically significant. Six of eighteen cardiac arrests in the non-RBT group were associated with a plasma $[K]$ in excess of $6.0 \mathrm{mmol} \cdot \mathrm{L}^{-1}$. An identifiable aetiology was present in all but one patient. In contrast, all the cardiac arrests in the RBT group had a plasma [K] in excess of $6.0 \mathrm{mmol} \mathrm{\textrm {L } ^ { - 1 }}$. The additional increment in plasma $[\mathrm{K}]$ during cardiac arrest in the RBT group, compared with the non-RBT group, was both statistically and clinically significant.

Several factors may have contributed to the development of hyperkalaemia during cardiac arrest. Both metabolic and respiratory acidosis may cause a modest elevation in plasma $[K]]^{3,4}$ However, as a group the non-RBT group was more acidotic than the RBT group. It is unlikely that a difference in acid base status can explain the higher arrest plasma [K] observed in the RBT group. Epinephrine is known to have a biphasic effect on plasma $[\mathrm{K}] .^{3}$ However, epinephrine administration during the cardiac arrests was not uniform and only three patients in the RBT group received epinephrine during resuscitation. Therefore it is difficult to speculate about the relationship between epinephrine administration and the plasma [K] during cardiac arrest in the RBT group. The role of hypovolaemia and low cardiac output in the genesis of hyperkalaemia must also be considered. A severe ischaemic insult may be associated with loss of intracellular potassium, which may redistribute within the systemic circulation and increase the plasma $[\mathrm{K}]$. Whether this is more likely to occur during cardiopulmonary resuscitation for cardiac arrest arising from hypovolaemia compared with other aetiologies, is not known. However, $\mathrm{pH}$ values in the RBT group were comparable with those in the non-RBT group. In addition the $\mathrm{PO}_{2}$ values were similar in both groups. The data, presented in Tables I and II, does not support the concept that the degree of cellular insult was greater in the RBT group, compared with the non-RBT group, during cardiac arrest.

Alternatively, the model simulation predicted that hyperkalaemia may arise during cardiac arrest as a consequence of rapid infusion of potassium-rich transfusate during a low-flow cardiac output state. Three factors must be taken into account.

The first is the potassium load in the transfusion. ${ }^{5-7}$ Although the transfused erythrocytes will regain the intracellular potassium which was lost during blood storage, this requires several days. ${ }^{8}$ Acutely the free potassium contained in the plasma fraction of a unit of blood must be dealt with as a potassium load. Table II shows that patients 1 through 6 received units of RBCconc $\geq 13$ days of age. (These children received units of RBCconc as rWB.) The plasma [K] in 20 units of rWB containing units of 14-day-old RBCconc was measured and found to range from $10-30 \mathrm{mmol} \cdot \mathrm{L}^{-1}$. Some of the patients received units of RBCconc $>14$ days of age. These patients may have been exposed to an even greater potassium concentration, since stored erythrocytes continue to loose intracellular potassium with increasing storage time..$^{5-7}$

The second factor concerns the rate of blood transfusion. Although it is recommended that whole blood be transfused at rates less than $0.3 \mathrm{ml} \cdot \mathrm{kg}^{-1} \cdot \min ^{-1}, 9$ in clinical practice the rate is determined by the rate of surgical blood loss which may well exceed $0.3 \mathrm{ml} \cdot \mathrm{kg}^{-1}$. $\min ^{-1}$

Consideration of the ratio $\dot{\mathrm{Q}}_{\mathrm{Tr}} \dot{\mathrm{Q}}_{\mathrm{Tor}}$ during RBT and cardiac arrest is also important. The cardiac output (CO) in awake children is about $120 \mathrm{ml} \cdot \mathrm{kg}^{-1} \cdot \mathrm{min}^{-1} \cdot{ }^{10} \mathrm{Car}$ diac output decreases by about ten per cent during anaesthesia. Acute blood loss of 30 per cent of blood volume, in dogs, has been shown to reduce cardiac output by 50 per cent. " In a child with a haematocrit of 0.3 , this would result in a cardiac output of $50 \mathrm{ml} \cdot \mathrm{kg}^{-1} \cdot \mathrm{min}^{-1}$ and a $\dot{Q}_{\mathrm{P}}$ of $35 \mathrm{ml} \cdot \mathrm{kg}^{-1} \cdot \mathrm{min}^{-1}$ (See Apendix). In fact, if chest compressions are required during hypovolaemic cardiac arrest, then a $\dot{Q}_{\mathrm{Pt}}$ of $35 \mathrm{ml} \cdot \mathrm{kg}^{-1} \cdot \mathrm{min}^{-1}$ may be an overestimate of cardiac output. During cardiac arrest, a $\dot{\mathrm{Q}}_{\mathrm{Tr}}$ of $5-10 \mathrm{ml} \cdot \mathrm{kg}^{-1} \cdot \mathrm{min}^{-1}$ could represent more than 20 per cent of the total venous return. Large-bore 
intravenous access allows transfusion rates greater than $100 \mathrm{ml} \cdot \mathrm{min}^{-1} .^{12}$ Although it was not possible to determine the absolute rate of blood transfusion during the period of cardiac arrest from the chart review, it was evident that units of rWB were administered quickly and transfusion rates may well have approached the physical maximum of the delivery system. In the RBT group, patients 1 through 6 (Table II) weighed less than $20 \mathrm{~kg}$ and all had large-bore intravenous access. The Hct $\mathrm{Tr}$ was assumed to be 0.5 and therefore a transfusion rate of 100-200 $\mathrm{ml} \cdot \mathrm{min}^{-1}$ could have represented a $\dot{Q}_{\operatorname{Tr}}$ of $50-100 \mathrm{ml} \cdot \min ^{-1}$ or up to $10 \mathrm{ml} \cdot \mathrm{kg}^{-1} \cdot \mathrm{min}^{-1}$ (See Appendix). If the $\dot{Q}_{\mathrm{Pt}_{1}}$ during cardiac arrest were $35 \mathrm{ml}$. $\mathrm{kg}^{-1} \cdot \mathrm{min}^{-1}$ then this $\dot{Q}_{\mathrm{Tr}}$ of $5-10 \mathrm{ml} \cdot \mathrm{kg}^{-1} \cdot \mathrm{min}^{-1}$ would represent a ratio of $\dot{\mathrm{Q}}_{\mathrm{Tr}} / \dot{\mathrm{Q}}_{\mathrm{Tot}}$ of $0.14-0.22$. Figure 2 suggests that this is the value of the ratio $\dot{\mathrm{Q}}_{\mathrm{Tr}} \dot{\mathrm{Q}}_{\mathrm{Tot}}$ at which the value of $\mathrm{K}_{\mathrm{Tr}}$ becomes critical in determining the value of $K_{\text {Tor }}$. We have already established that the $K_{\text {Tr }}$ for patients in the RBT group (Table II) probably ranged from 10 to $30 \mathrm{mmol} \cdot \mathrm{L}^{-1}$.

The third factor is the physiological response to potassium challenge. Although potassium distribution is well described by a two-compartment model, this applies only to steady state conditions. ${ }^{3,13} \mathrm{We}$ postulated that during massive haemorrhage and rapid blood transfusion, the time would be too short for an appreciable amount of potassium to be lost or gained from the extracellular compartment. Potassium would behave as if it distributed within a single compartment and its behaviour during RBT could therefore be approximated with linear first order kinetics, assuming that recirculation of compartmental blood did not occur. Therefore the rate of rise of $K(t)$ was described by the exponential equation':

$K(t)=K_{\text {Tot }}\left(1-e^{-k(t)}\right)+\left(K_{o} e^{-k(t)}\right)$

The rate constant, $k$, was the ratio of $\dot{\mathrm{Q}}_{\mathrm{Tot}} / \mathrm{V}_{1}$.

Values for $\dot{\mathrm{Q}}_{\mathrm{Tot}}$ during cardiac arrest have already been discussed and estimates of $V_{1}$, the volume of the central circulation, are detailed in the Appendix. It was assumed that the vascular and interstitial compartments equilibrated instantaneously, allowing the central compartment to be considered as a single compartment of volume $V_{1}$. The use of the pulmonary extracellular compartment to approximate $V_{1}$ may have overestimated the actual $V_{1}$. However, the estimate of $K(t)$ was not intended to give an exact value but rather to approximate the rate of rise of $K(t)$, in order to determine its relevance to the data in Table Il. Figure 3 shows that the increase in $K(t)$ occurred rapidly. It suggested that hyperkalaemia during $R B T$ may occur acutely during rapid blood administration into a hypovolaemic low cardiac output state.

In the RBT group none of the patients with an elevated plasma $[K]$ required specific treatment for hyperkalaemia.
Yet in all cases the plasma $[\mathrm{K}]$ was $<5.5 \mathrm{mmol} \cdot \mathrm{L}^{-1}$ within 30 minutes of the cardiac arrest. This supports the notion that once an effective cardiac output had been established the potassium-rich blood in the central circulation was circulated and the potassium distributed within total body water.

In conclusion, we have demonstrated that small children who received a rapid transfusion of potassium-rich blood during a low cardiac output state had a high incidence of hyperkalaemia. The documented plasma potassium concentrations during cardiac arrest are in agreement with those predicted from the model simulations. Theoretically, the predisposing factors for the development of hyperkalaemia during RBT are (1) the physiological response to the potassium challenge, (2) the volume of the central compartment, (3) the contribution of the rate of blood transfusion to the total venous return, and (4) the potassium concentration of the transfusate. The acute response to potassium challenge is redistribution and dilution. Given the small volume of the central compartment, it is obvious that if the transfusion rate is high relative to the cardiac output, and if the blood is old, and associated with a potassium-rich plasma fraction, then RBT during hypovolaemic cardiac arrest may be associated with hyperkalaemia.

Hyperkalaemia during RBT and a low cardiac output state would remain a biochemical curiosity except that the coronary circulation receives the potassium-rich outflow from the central circulation. The transmembrane potassium concentration gradient is central to the definition of the resting membrane potential, as defined by the Nernst equation. Hyperkalaemia is arrythmogenic. In addition, in vitro, a $[\mathrm{K}]$ of $8-15 \mathrm{mmol} \cdot \mathrm{L}^{-1}$ has been shown to result in ineffective cardiac contraction, ${ }^{14}$ and in vivo, cardiac output varies inversely with the potassium concentration. ${ }^{15}$ Therefore, rapid administration of potassium-rich blood may depress cardiac output, allowing the ratio $\dot{\mathrm{Q}}_{\mathrm{Tr}} / \dot{\mathrm{Q}}_{\mathrm{Tot}}$ to rise and resulting in an acute increase in the plasma $[\mathrm{K}]$ of the central circulation, which may offset the desired effect of an increased preload. In addition, rapid transfusion of stored blood may result in hypothermia, acidaemia and hypocalcaemia, all factors which may further depress cardiac output. 9,16,17

\section{Acknowledgement}

The authors wish to thank Dr. M. Halperin for helping to formulate the ideas expressed in this paper.

\section{Appendix}

FreeK $_{\mathrm{Tot}}=$ FreeK $_{\mathrm{Pt}}+$ FreeK $_{\mathrm{Tr}}$
FreeK $_{\mathrm{Tot}}=\left[\mathrm{K}_{\mathrm{Pt}_{\mathbf{t}}} \times \dot{\mathrm{Q}}_{\mathrm{Pt}}\right)+\left(\mathrm{K}_{\mathrm{Tr}} \times \dot{\mathrm{Q}}_{\mathrm{Tr}}\right)$ 
where $K_{P_{t}}$ and $K_{T r}$ refer to the plasma [K] in the venous retum of the patient and the transfusion, respectively.

Since acutely potassium distributes only within the plasma fraction of blood, values for volumes and flows were referenced to plasma such that:

$\dot{\mathrm{Q}}_{\mathrm{Pt}}=\left(1-\mathrm{Hct}_{\mathrm{Pt}}\right) \times \mathrm{VR}$

$\dot{\mathrm{Q}}_{\mathrm{Tr}}=\left(1-\mathrm{Hct}_{\mathrm{Tr}}\right) \times \mathrm{TR}$

where VR is the venous return of the patient and TR is the transfusion rate; Hct $_{\mathrm{P}_{t}}$ and $\mathrm{Hct}_{\mathrm{Tr}}$ refer to the haematocrit of the patient and transfusion, respectively.

$\dot{\mathrm{Q}}_{\mathrm{Pt}}$ and $\dot{\mathrm{Q}}_{\mathrm{Tr}}$ combine to give a total flow, $\dot{\mathrm{Q}}_{\mathrm{Tot}}$ such that:

$\dot{\mathrm{Q}}_{\mathrm{Tot}}=\dot{\mathrm{Q}}_{\mathrm{Pt}}+\dot{\mathrm{Q}}_{\mathrm{Tr}}$

Therefore,

FreeK $_{\text {Tot }}=\mathbf{K}_{\text {Tot }} \times \dot{\mathbf{Q}}_{\text {Tot }}$

where $K_{\text {Tot }}$ is the plasma potassium concentration of the inflow.

Combining equations $\mathrm{A} 1$ and $\mathrm{A} 2$ and dividing both sides of the equation by $\dot{\mathrm{Q}}_{\mathrm{Tot}}$ :

$K_{\mathrm{Tot}}=\left(K_{\mathrm{Pt}} \times \frac{\dot{\mathrm{Q}}_{\mathrm{Pt}_{\mathrm{t}}}}{\dot{\mathrm{Q}}_{\mathrm{Tot}}}\right)+\left(\mathrm{K}_{\mathrm{Tr}} \times \frac{\dot{\mathrm{Q}}_{\mathrm{Tr}}}{\dot{\mathrm{Q}}_{\mathrm{Tot}}}\right)$

$V_{1}$, the volume of the central circulation, represented the combined volume of the pulmonary $\left(V_{1 A}\right)$ and cardiac $\left(V_{1 B}\right)$ extracellular volume such that:

$\mathrm{V}_{1}=\mathrm{V}_{1 \mathrm{~A}}+\mathrm{V}_{1 \mathrm{~B}}$

$V_{\text {IB }}$ was assumed to equal three per cent of total blood volume which was assumed to be $75 \mathrm{ml} \cdot \mathrm{kg}^{-1}$. Therefore $\mathrm{V} 1_{\mathrm{B}}=1.6 \mathrm{ml} \cdot \mathrm{kg}^{-1}$

The pulmonary ECF volume $\left(V_{1 A}\right)$ was equal to the sum of its interstitial volume (PISF) and its blood volume (PBV). Values for awake PBV range from 10-20 per cent of total blood volume. It was assumed that PBV was 15 per cent of total blood volume of which 70 per cent was plasma $\left(7.9 \mathrm{ml} \cdot \mathrm{kg}^{-1}\right){ }^{18,19}$ The PISF was assumed to equal 15 per cent of the total wet weight of both lungs. ${ }^{3}$ For a child aged 1-3 $\mathrm{yr}(10-15 \mathrm{~kg})$ the weight of both lungs ranges from $112-166 \mathrm{~g},{ }^{20}$ giving a PISF of $1.7 \mathrm{ml}$. $\mathrm{kg}^{-1}$. Therefore:

$$
\begin{aligned}
\mathrm{V}_{\mathrm{A}_{\mathrm{A}}} & =\mathrm{PBV}+\mathrm{PISF} \\
& =7.9 \mathrm{ml} \cdot \mathrm{kg}^{-1}+1.7 \mathrm{ml} \cdot \mathrm{kg}^{-1} \\
& =9.6 \mathrm{ml} \cdot \mathrm{kg}^{-1}
\end{aligned}
$$

Substituting in Equation 4:

$$
\begin{aligned}
\mathrm{V}_{1} & =\mathrm{V}_{1 \mathrm{~A}}+\mathrm{V}_{1 \mathrm{~B}} \\
& =9.6 \mathrm{ml} \cdot \mathrm{kg}^{-1}+1.6 \mathrm{ml} \cdot \mathrm{kg}^{-1} \\
& =11.2 \mathrm{ml} \cdot \mathrm{kg}^{-1} .
\end{aligned}
$$

\section{References}

1 Marsaqlia $G$, Thomas $E D$. Mathematical consideration of cross circulation and exchange transfusion. Transfusion 1971; 71: 216-9.

2 Zar H. Biostatistical Analysis. 2nd ed. Englcwood Cliffs: Prentice-Hall, Inc. 1984.

3 Halperin $M$, Goldstein $M$. Potassium physiology. In: Halperin M, Goldstein M (Eds.). Fluid, Electrolyte and Acid Base Emergencies. Toronto: WB Saunders 1988; 208-51.

4 Adroqué HJ, Madias NE. Changes in plasma potassium concentration during acute acid-base disturbance. Am J Med 1981; 71: 456-7.

5 Moore GL, Peck CG, Sohmer PR, Zuck TF. Some properties of blood stored in CPDA-1 solution. Transfusion 1981; $21: 135-8$.

6 Michael JM, Dorner I, Bruns D, Ladenson JH, Sherman LA. Potassium load in CPD-preserved whole blood and two types of packed red blood cells. Transfusion 1975; 15 : 144-9.

7 Brown KA, Bissonnette B, MacDonald M, Poon AO. Hyperkalaemia during paediatric craniofacial surgery. Can J Anaesth 1990; 37: 401-8.

8 Valerie $C R$, Hirsch NM. Restoration in vivo of erythrocytc adenosine triphosphate, 2,3-diphosphoglycerate, potassium ion and sodium ion concentrations following the transfusion of acid-citrate-dextrose-stored human red blood cells. J Lab Med 1969; 73: 722-33.

9 Coté CJ. Blood replacement and blood product management. In: Ryan JF, Todres ID, Coté CJ, Goudsouzian NG (Eds.). A Practice of Anaesthesia for Infants and Children. Orlando: Grune and Stratton 1986; 123-32.

10 Guyton $A C$. Cardiac output, venous return and their regulation. In: Guyton AC (Ed.). Textbook of Medical Physiology. 5th ed., Philadelphia: WB Saunders 1976; 295-310.

11 Guyton $A C$. Circulatory shock and physiology of its treatment. In: Guyton AC (Ed.). Textbook of Medical Physiology. 5th ed., Philadelphia: WB Saunders 1976; 357-69.

12 Dula DJ, Muller HA, Donovan JW. Flow rate variance of commonly used intravenous infusion techniques. J Trauma 1981; 21: 480-2.

13 Sterns RH, Feig PU, Pring M, Guzzo J, Singer I. Disposition of intravenous potassium in anuric man: a kinetic analysis. Kidney Int 1979; 15: 651-60.

14 Guyton $A C$. Heart muscle. The heart as a pump. In: Guyton AC (Ed.). Textbook of Medical Physiology. 5th ed., Philadelphia: WB Saunders 1976; 160-75. 
15 Scheller MS, Mazzei WJ, Zornow MH, Mitchell MM. A comparison of the effects of central and peripheral bolus injections of potassium chloride on aortic root potassium concentrations in swine. Journal of Cardiothoracic Anesthesia 1989; 3: 172-5.

16 Dzik WH, Kirkley $S A$. Citrate toxicity during massive blood transfusion. Transfusion Medicine Reviews 1988; 2: 76-94.

17 Taylor WC, Gillis CN, Nash CW, Kullman GL. Experimental observations on cardiac arrhythmia during exchange transfusion in rabbits. J Pediatrics 1961; 58: 470-6.

18 Guyton $A C$. The systemic circulation. In: Guyton AC (Ed.). Textbook of Medical Physiology. 5th ed., Philadelphia: WB Saunders 1976; 237-49.

19 Nunn JF. The pulmonary circulation. In: Nunn JF (Ed.). Applied Respiratory Physiology, 2nd ed., London: Butterworths 1977; 249.

20 Copoletta JM, Wolbach SB. Body length and organ weights of infants and children. Am J Path 1933; 9: 55. 